\title{
HEALTH AND QUALITY OF ZINC COATED WHEAT SEEDS DURING STORAGE
}

\author{
SANIDADE E QUALIDADE DE SEMENTES DE TRIGO RECOBERTAS COM ZINCO \\ DURANTE O ARMAZENAMENTO
}

\section{Lilian Madruga de TUNES ${ }^{1}$; Daniele Brandstetter RODRIGUES ${ }^{1}$; Gizele Ingrid GADOTTI ${ }^{2}$; Andréia da Silva ALMEIDA ${ }^{1}$; Ewerton GEWEHR ${ }^{1}$; Aline Klug RADKE ${ }^{1}$ \\ 1. Programa de Pós-Graduação em Ciência e Tecnologia de Sementes, Departamento de Fitotecnia, Universidade Federal de Pelotas - UFPel/FAEM, Capão do Leão, RS, Brasil. lilianmtunes@ yahoo.com.br; 2. Professora do Centro de Engenharias - UFPel, Pelotas,- RS, Brasil.}

\begin{abstract}
The objective was to evaluate the effect of seed wheat coated with zinc, in its physiological, sanitary attributes and enzyme quality, during storage. We used two batches of seed, for seed treatment, we used commercial product as a source of zinc in the form of $\mathrm{ZnSO}_{4}$, along with fungicide and polymer. It was tested for levels 0 , 1, 2, 3 and $4 \mathrm{~mL} \mathrm{ZnSO}_{4} \mathrm{~kg}^{-1}$ seed. The physiological quality, during the storage period, was analyzed by the tests: moisture content, hectoliter weight, germination, emergence, index emergence rate, tetrazolium and sanity test. It was concluded that the doses $3 \mathrm{~mL}$ and $4 \mathrm{~mL}$ of $\mathrm{ZnSO}_{4}$ to assist in the ultimate expression of the seeds physiological quality, until six months stocked. This coating promotes a smaller reduction in the viability of seeds, furthermore, results in a lower incidence of fungi on seeds during storage. Also help to maximize the expression of physiological seed quality of higher and lower quality, respectively. The micronutrient zinc associated with fungicide and polymer had a lower incidence of fungi during the storage period.
\end{abstract}

KEYWORDS: Physiological quality. Sanity. Seed treatment. Triticum aestivum L.

\section{INTRODUCTION}

The nourished plant with this micronutrient may present an increase in the initial development, in adverse conditions and poor soil of zinc. In addition, fertilization can be avoided via soil and foliar thus leading to a reduction in production costs. Seed coating, coupled with other management practices, has contributed to reduce costs, improve product quality, reduce environmental damage and offer good protection to the seeds in the field and during storage.

Products such as wheat and barley, generally, need to be stored for periods of six to seven months. For seeds are preserved with minimal deterioration, there must be an adequate control on the storage system, an alternative would be seed coating, but this should be properly monitored by physiological, enzymatic and sanitary potential.

Another important factor that must be analyzed during the period of storage is sanitary quality of wheat seeds, even when they are coated with pesticides. The incidence of microorganisms in seeds, according to Lima et al. (2006), is responsible for pre-emergence death of seedlings in the field, loss of vigor and germination during storage, with consequent reduction of the final stand in the field.

The occurrence of diseases is one of the most important things to production stagnation. Given the above, research is needed on methods to assist in maximizing the quality of wheat seeds during storage. The increasing demands on seed quality by the consumer market have led to an intense monitoring in the seeds, as seed treatment with micronutrients (provision of a disability), storage as a quality method and fast control and effective through sanity.

Thereby, the objective of this study was to evaluate the effect of wheat seed coating with zinc through physiological and sanitary attributes during storage.

\section{MATERIAL AND METHODS}

We used two seed lots of wheat of the same cultivar, crop (2009/10) and site of production (NãoMe-Toque/RS, Brazil), one of high quality and one of low quality, based on first germination count of 80 and $68 \%$ for the high and low lots, respectively. Preliminary tests were conducted. It was checked that both lots had dormancy and dormancy breaking was realized.

Quimifol Seed 78® was used, with a source of zinc as zinc sulfate $\left(\mathrm{ZnSO}_{4}\right)$ as active ingredient, in which each $100 \mathrm{~mL}$ provides $78 \mathrm{~g}$ of zinc. It was tested levels $0,1,2,3$ and $4 \mathrm{~mL}$ of $\mathrm{ZnSO}_{4} \mathrm{~kg}^{-1}$ seed, also was added $3 \mathrm{~mL}$ of fungicide (carboxim + thiram), $0.8 \mathrm{~mL}$ of polymer Poly Seed CF® (high quality lot) or Collor Seed ${ }^{\circledR}$ polymer (low quality lot) and sufficient water to complete spray volume 
of $15 \mathrm{~mL}$ per $\mathrm{kg}$ of seed. In the control was adjusted the volume of water as other treatments. The use of different polymers was only to different lots by color, Collor Seed® polymer red and Poly Seed $\mathrm{CF}{ }^{\circledR}$ colorless . The final volume were equal for all treatments, because they were adjusted to complete volume with water.

Seed coating was performed manually, using $0.3 \mathrm{~kg}$ of seed per experimental unit, with mixture of products made in plastic bags and after addition of seeds. The seeds were stirred until complete product distribution and coverage of seeds. Then, coated seeds were placed to dry at room temperature for 24 hours and after they were stored either at room temperature for a period of 6 months.

Tests were conducted for evaluation of physiological and health attributes of wheat seeds coated with zinc, during the six months of storage at room temperature and without control of relative humidity. Evaluations were performed immediately after coating (initial analysis) and every three months of storage. The quality during storage was evaluated by water content, hectoliter weight, germination, seedling emergence, emergence speed index and tetrazolium test.

Moisture content (MC): determined by oven method at $105{ }^{\circ} \mathrm{C} \pm 3{ }^{\circ} \mathrm{C}$ for 24 hours, in an oven with forced air circulation, using four replicates of five grams of seeds per treatment, according to Brazilian Rules - RAS (BRASIL, 2009). Hectoliter weight (HW): was evaluated by weighing of four samples in hectoliter weighing-machine, with a capacity of one quart of seed and the results expressed in kilograms per one hundred liters (kg $100 \mathrm{~L}^{-1}$ ), based on Brazilian Rules - RAS (BRASIL, 2009). Germination (G): performed with four replicates of 100 seeds per lot, it was seeded in paper towels called "germitest", moistened with distilled water at a ratio of 2.5 times the mass of dry paper. The rolls were placed inside plastic bags and maintained in germination chamber, set at $20{ }^{\circ} \mathrm{C}$. The evaluation was performed eight days after seeding (BRASIL, 2009). Seedling emergence (SE): subjects were four replicates of 50 seeds for each treatment. It was sown in plastic trays filled with sand at a depth of $2.0 \mathrm{~cm}$ and maintained at $20^{\circ} \mathrm{C}$ in a controlled environment. Irrigations were performed whenever necessary, and evaluation occurred 15 days after sowing, when seedling emergence has become constant, was by computed the percentage of seedlings (NAKAGAWA, 1999). Emergence speed index (ESI): conducted jointly with seedling emergence test, through daily counts of the number of seedlings (seedling length of 1.0 $\mathrm{cm}$ above ground) until the fifteenth day (until stabilization of seedlings number). For each replicate, we calculated ESI, adding to the number of seedlings every day divided by number of days elapsed from sowing, as Maguire (1962). Tetrazolium Test (TZ): seeds were soaked in distilled water for 18 hours at $20{ }^{\circ} \mathrm{C}$ before being subjected to longitudinal section. After sectioning, seeds were placed in the dark, in $25 \mathrm{~mL}$ beakers, containing solution of 2,3,5 trifrenil tetrazolium chloride to $1 \%$, for 3 hours (BRASIL, 2009). After coloring, the solution was drained and seeds rinsed with tap water. Evaluation was based on the criteria proposed by ISTA (2008), to determine the percentage of viable seeds.

Evaluation of sanitary quality of wheat seeds was performed by sanitary test, by method of filter paper or "Blotter test". For this we used 200 seeds of each treatment, divided into four subsamples of 50, placed in plastic boxes called "gerbox", previously disinfested with alcohol and hypochlorite $(1 \%)$ for a minute, under two sheets of filter paper moistened with sterile distilled water. Seeds were incubated at $25{ }^{\circ} \mathrm{C}$, with 12 hours photoperiod, of 24 hours. Then, for the inhibition of germination, seeds were submitted to freezing method for 24 hours. After this procedure, were incubated at $25{ }^{\circ} \mathrm{C}$ for seven days with 12 hours of light regime following methodology proposed by Brasil (2009). Analyzes were performed with a laboratory magnifying glass and optical microscope for observation of morphological structures of fungi, which were identified at genus level, with aid of specialized bibliography of Barnett and Hunter (1998), determining the percentage of seeds infected by fungi.

Experimental design was completely randomized with four replications. Averages were subjected to analysis of variance and compared by Tukey test at $5 \%$ of probability and also was done polynomial regression. Statistical analysis was performed using Sisvar (FERREIRA, 2000).

\section{RESULTS AND DISCUSSION}

Assessing coating quality of seeds was performed using a visual rating scale ranging from 0 (naked seed) to 10 (excellent coverage), checking uniformity of coating and appearance of seeds with 50 seeds per experimental unit. Wheat seeds coated (Figure 1) had grade 9 in light pink color (high quality lot) and score 8 in deep pink color (low quality lot), with a good adhesion of polymer.

Data analysis showed an association between polymer seed treatments, where seed 
coating showed good appearance, color, distribution and adhesion of product to surface thereof (Figure $1)$.
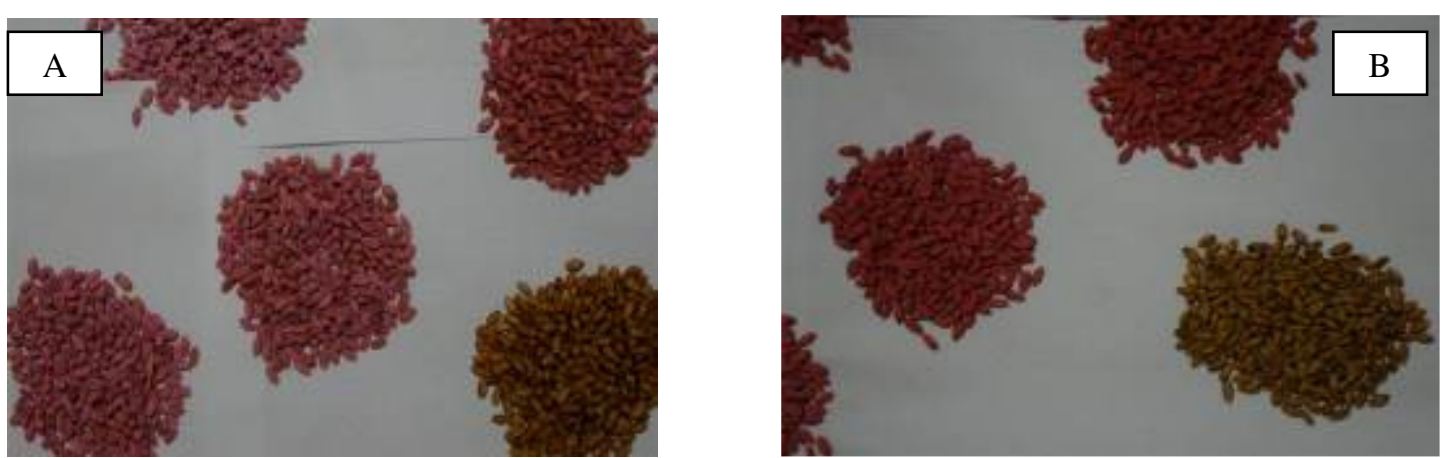

Figure 1. View of seeds coated with zinc, fungicide, polymer and water. A) High quality lot and B) low quality lot. UFSM, Santa Maria, RS, Brazil, 2011.

In evaluating seed quality, water content, hectoliter weight test and germination are important factors, as well as growth and development of seedlings and seed viability (AOSA, 2012; BRASIL, 2009).

During the data analysis of moisture content (Table 1) the data of the seeds obtained in initial analysis and storage for three and six months in uncontrolled environment. It is observed that water content of seeds was not influenced by application of $\mathrm{ZnSO} 4$ during periods of storage. In high quality lot, seeds had water content at the beginning of storage, from 12.4 to $12.7 \%$. Treatments of low quality lot showed water content at the beginning of storage, from 12.9 to $13.2 \%$. After three and six months of storage, water content of different treatments of both lots, remained similar, revealing uniformity due to hygroscopic equilibrium with uncontrolled environment. Moisture increase occurs in environment due to seed hygroscopicity, which provides a dynamic process of moisture exchange with surrounding air until it reaches the point of equilibrium moisture content. The presence of polymer in seed coating can be considered as a protection to prevent any sudden changes in water absorption by seeds, in periods of high relative humidity and low temperature.

Table 1. Water content of wheat seeds, high and low quality lot after coating with different doses of zinc. UFSM, Santa Maria, RS, Brazil.

\begin{tabular}{|c|c|c|c|c|}
\hline \multirow{2}{*}{$\mathrm{ZnSO}_{4}$ doses $(\mathrm{mL})$} & \multirow{2}{*}{ Lot } & & Water content $(\%)$ & \\
\hline & & 0 & 3 & 6 \\
\hline 0 & & 12.4 & 12.5 & 12.6 \\
\hline 1 & & 12.6 & 12.8 & 12.9 \\
\hline 2 & High quality & 12.6 & 12.8 & 12.7 \\
\hline 3 & & 12.6 & 12.7 & 12.7 \\
\hline 4 & & 12.7 & 12.7 & 13.1 \\
\hline 0 & & 12.9 & 12.9 & 12.5 \\
\hline 1 & & 13.1 & 13.2 & 13.3 \\
\hline 2 & Low quality & 13.0 & 13.0 & 13.1 \\
\hline 3 & & 13.1 & 13.1 & 13.2 \\
\hline 4 & & 12.9 & 13.1 & 12.8 \\
\hline
\end{tabular}

Based on hectoliter weight test data, it is clear that seeds of both lots coated with different doses of $\mathrm{ZnSO} 4$ storage for six months, no showed significant differences between treatments (Table 2). Hectoliter weight test is a varietal characteristic which, among a number of external factors can be influenced by seeds water content and chemical treatment to which they are submitted. From results observed, it is possible to infer also that some products can not influence this characteristic according to material nature used in coating. Hectoliter weight test (HW) is an index relating to 
yield as well, is higher than higher value obtained. The fact that treatment has a higher HW value does not represent that is the best quality. Accordingly Guarienti (1996) this relationship will only be significant when comparing treatments with different HW values, because many factors are the cause of errors in determining this index, for example, gaps between seeds, water content and type and amount of impurities present in the sample. It is noteworthy that, on average, high quality lot showed HW with more $5 \mathrm{~g}$ than low quality lot, i.e. $6 \%$ superior.

Table 2. Hectoliter weight (HW) test of wheat seed, high and low quality lot after coating with different doses of zinc. UFSM, Santa Maria, RS, Brazil.

\begin{tabular}{|c|c|c|c|c|}
\hline \multirow{2}{*}{$\begin{array}{l}\text { Doses of } \mathrm{ZnSO}_{4} \\
(\mathrm{~mL})\end{array}$} & \multirow[t]{2}{*}{ Lot } & \multicolumn{3}{|c|}{$\begin{array}{l}\mathrm{HW}(\mathrm{kg} / 100 \mathrm{~L}) \\
\text { Month(s) }\end{array}$} \\
\hline & & 0 & 3 & 6 \\
\hline 0 & \multirow{5}{*}{ High quality } & 77.31 & 77.28 & 77.35 \\
\hline 1 & & 77.08 & 77.15 & 77.26 \\
\hline 2 & & 77.20 & 77.18 & 77.23 \\
\hline 3 & & 77.03 & 77.15 & 77.11 \\
\hline 4 & & 77.10 & 77.19 & 77.17 \\
\hline F Test & & $0.96^{\mathrm{ns}}$ & $0.83^{\mathrm{ns}}$ & $1.31^{\mathrm{ns}}$ \\
\hline 0 & \multirow{6}{*}{ Low quality } & 72.18 & 72.26 & 72.33 \\
\hline 1 & & 71.92 & 72.00 & 72.21 \\
\hline 2 & & 72.07 & 72.22 & 72.30 \\
\hline 3 & & 72.11 & 72.18 & 72.27 \\
\hline 4 & & 72,01 & 72.15 & 72.25 \\
\hline F Test & & $1.23^{\mathrm{ns}}$ & $1.07^{\mathrm{ns}}$ & $0.77^{\mathrm{ns}}$ \\
\hline
\end{tabular}

$*$ and ${ }^{\mathrm{ns}}-$ significant to $5 \%$ of probability, and no significant by Tukey (5\%), respectively.

Figure 2 shows data of germination in initial period and after three and six months of storage. High quality lot no showed significant difference of germination potential between doses of zinc sulfate tested during the entire period of storage (Figure 2a). These results are in agreement with those found for Ohse et al. (2000), to conclude that coating rice seeds with zinc no promoted difference on germination. Likewise, Vieira and Moreira (2005) found no difference in germination of rice seeds coated with zinc. Also Funguetto et al. (2010) analyzing coating in rice seed with zinc source,

a) High quality lot

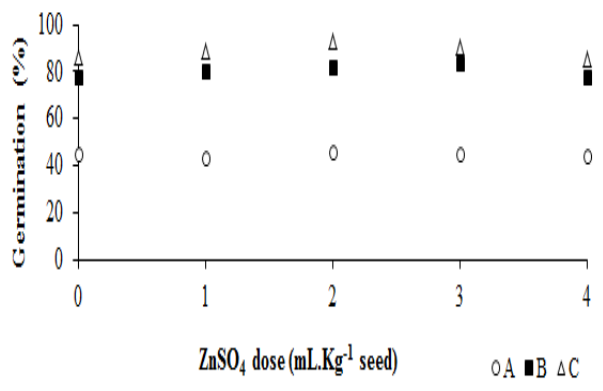

fungicide and polymer found no difference in germination. However, in sorghum seeds treated with zinc, Yagi et al., (2006) reported a reduction in germination percentage. The same was observed by Pereira et al., (2005) in film coating on corn seeds, registering a reduction of 2 percentage points in germination potential. In soybean, Trentini et al., (2005), found no significant differences on seeds germination coated with AGL 205 film and fungicide. b) Low quality lot

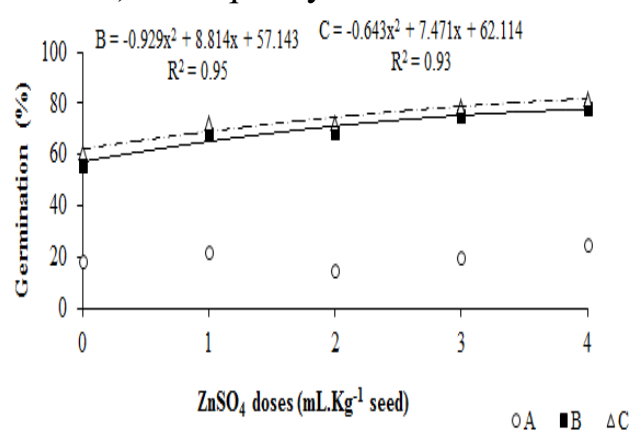

Figure 2. Seed wheat germination, high quality and low quality lot, after coating with different doses of zinc. UFSM, Santa Maria, RS, Brazil. * A) initial data of germination; B) three months of storage; C) six months of storage. 
Seeds germination of low quality seed lot (Figure 2b) showed no difference in initial data evaluation. However, in three and six months of storage, seed germination increased as $\mathrm{ZnSO}_{4}$ doses were increasing. The seeds expressed their maximum potential in dose $4 \mathrm{~mL}$ of $\mathrm{ZnSO}_{4}$ in three and six months of storage.

In Figures 3 and 4 are presented data from seedling emergence to 15 days after sowing and emergence speed index. For emergency (Figure 3a), there is the initial data and three months of storage that high quality lot performed better when seeds were coated with a dose of $3 \mathrm{~mL}$ of $\mathrm{ZnSO}_{4}$. Low quality lot gradually increased seedling emergence, over storage period, being dose of $4 \mathrm{~mL}$ of $\mathrm{ZnSO}_{4}$, showed the most significant results. According Albuquerque et al., (2010), zinc applied to seeds may be fully absorbed by seedling, especially in sand which has no loss of nutrient. a) High quality lot

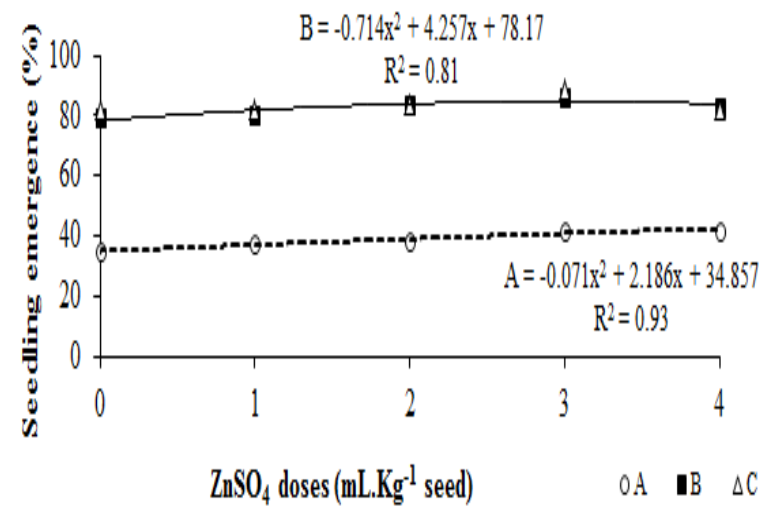

b) Low quality lot

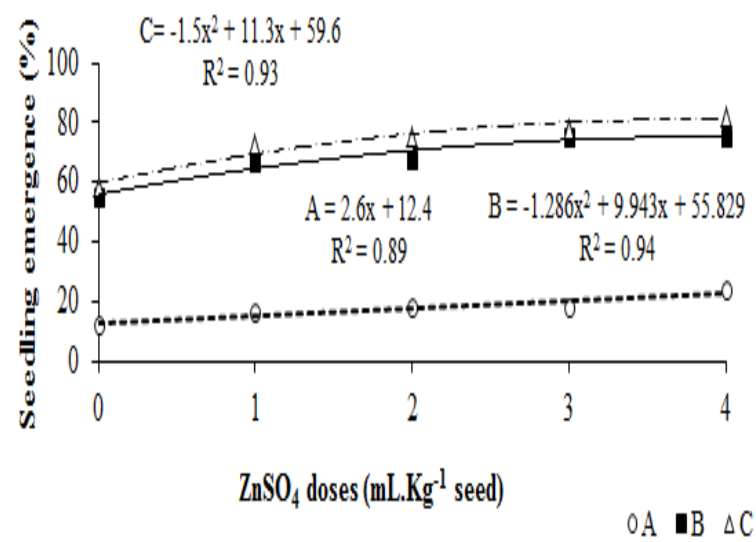

Figure 3. Seedling emergence of wheat, high and low quality lot, after coating with different doses of zinc. UFSM, Santa Maria, RS, Brasil. * A) initial data of germination; B) three months of storage; C) six months of storage.

a) High quality lot

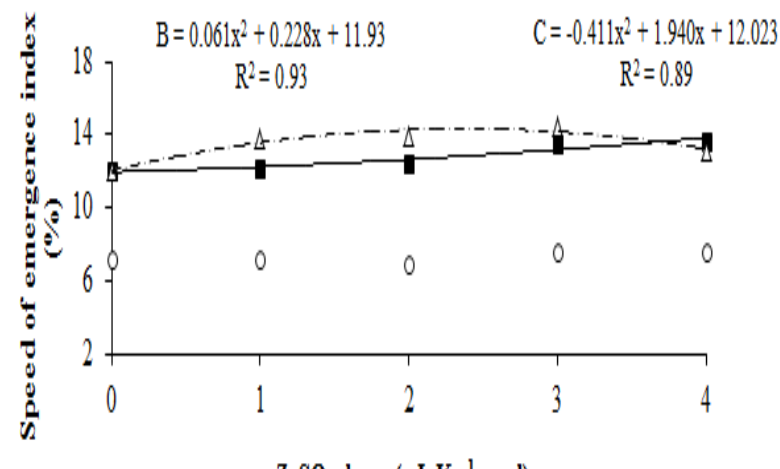

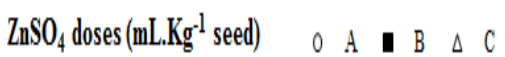

b) Low quality lot

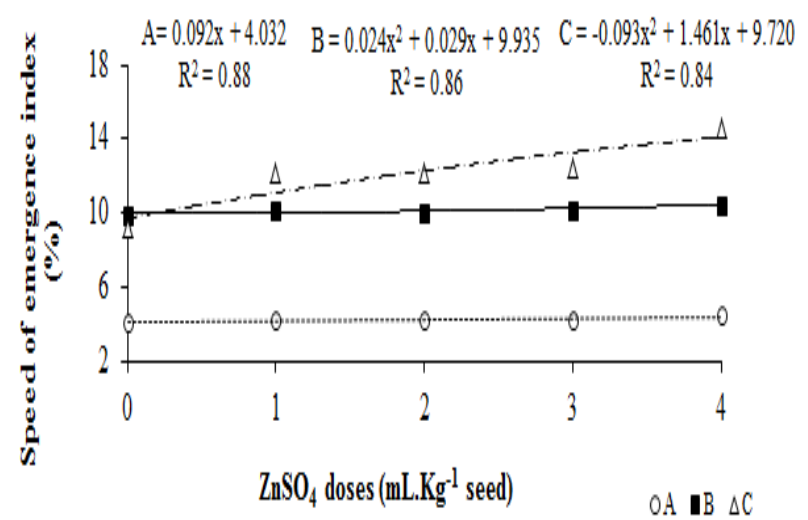

Figure 4. Emergence Speed Index of wheat, high and low quality lot, after coating with different doses of zinc. UFSM, Santa Maria, RS, Brasil. * A) initial data of germination; B) three months of storage; C) six months of storage.

Concerning to emergence speed index (Figure 4a), only in initial data seeds from high quality lot did not differ between doses tested doses, however, for low quality lot, there was variation during the storage process(Figure $4 b$ ).

In general, we can infer that the application of zinc in seeds influenced seedling emergence speed index and seedling emergence of wheat. Moreover, the difference found when comparing zero dose and other doses explained by early seed roots, enriched with zinc, are in direct contact with the nutrient (MELLO PRADO et al., 2007), improving germination and vigor (RIBEIRO AND SANTOS, 1996). Increase in seedlings initial 
performance after treatment with $\mathrm{ZnSO}_{4}$, was also verified by Mello Prado et al., (2007).

In both seedling emergence and emergence speed index variables, the dose of $3 \mathrm{~mL}$ of $\mathrm{ZnSO}_{4}$ $\mathrm{kg}^{-1}$ seed was more responsive to zinc, to seeds for low quality lot. Zinc, despite being an essential micronutrient, can affect growth and normal metabolism of plant species, present in excess levels in the environment, causing a phytotoxic effect (ALBUQUERQUE et al., 2010). The same was observed for seeds from low quality lot, which showed more significant results at a dose of $4 \mathrm{~mL}$ $\mathrm{ZnSO}_{4} \mathrm{~kg}^{-1}$ seed. Thus, these levels of zinc were not enough to cause injury to seedling growth or cause symptoms of toxicity. According to Ribeiro and Santos., (1996), the enhanced content in seeds of $\mathrm{ZnSO}_{4}$ about 18 times, was not toxic to corn seeds, allowing a greater supply of zinc to the beginning of seedling growth.

The evaluation of tetrazolium test was performed according to a visual comparison in Figure 5. In the tetrazolium test (Table 3), two lots of wheat seeds analyzed showed no significant difference between tested doses of $\mathrm{ZnSO}_{4}$, during storage at room conditions with uncontrolled temperature and relative humidity.

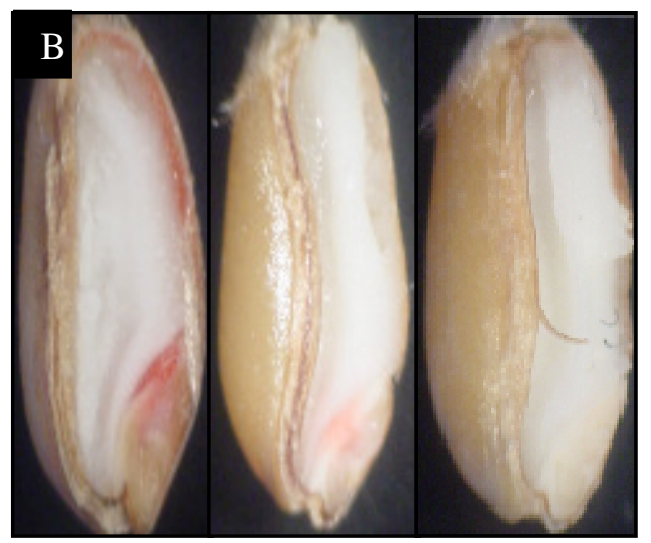

Figure 5. Tetrazolium test on wheat: viable seeds (A) and non-viable (B). UFSM, Santa Maria, RS, Brazil.

Table 3. Tetrazolium test in wheat seeds, high and low quality lot, after coating with different doses of zinc. UFSM, Santa Maria, RS, Brazil.

\begin{tabular}{|c|c|c|c|c|}
\hline $\begin{array}{l}\mathrm{ZnSO}_{4} \text { doses } \\
(\mathrm{mL})\end{array}$ & Lot & $\begin{array}{l}\text { Tetrazolium } \\
\text { (initial) }\end{array}$ & $\begin{array}{l}\text { Tetrazolium } \\
3 \text { months of storage }\end{array}$ & $\begin{array}{l}\text { Tetrazolium } \\
6 \text { months of storage }\end{array}$ \\
\hline & & $\%$ viability & & \\
\hline 0 & & 90.0 & 90.0 & 91.0 \\
\hline 1 & & 91.0 & 91.0 & 92.0 \\
\hline 2 & High quality & 91.0 & 91.0 & 93.0 \\
\hline 3 & & 90.0 & 90.0 & 92.0 \\
\hline 4 & & 93.0 & 91.0 & 94.0 \\
\hline F test & & $0.55^{\mathrm{ns}}$ & $0.91^{\mathrm{ns}}$ & $1.02^{\mathrm{ns}}$ \\
\hline 0 & & 82.0 & 82.0 & 83.0 \\
\hline 1 & & 82.0 & 82.0 & 84.0 \\
\hline 2 & Low quality & 83.0 & 83.0 & 83.0 \\
\hline 3 & & 84.0 & 84.0 & 84.0 \\
\hline 4 & & 82.0 & 83.0 & 85.0 \\
\hline F test & & $1.03^{\mathrm{ns}}$ & $1.32^{\mathrm{ns}}$ & $1.11^{\mathrm{ns}}$ \\
\hline
\end{tabular}

Figure 6 shows data regarding sanity of wheat seeds during storage period for high quality lot. Fungi found in seeds with six months of storage were Fusarium sp., Alternaria sp. and Penicillium sp. In initial data, the seeds were subjected to zero dose showed $45 \%$ of Fusarium sp., in contrast, the dose of $3 \mathrm{~mL}$ of $\mathrm{ZnSO}_{4}$ (fungicide + polymer and water) that was had lower percentage incidence of this pathogen, which also observed higher dry mass of roots and shoots, as well as seedling emergence, suggesting interference of fungus in seed 
metabolism, providing greater change in quality (Figure 6).
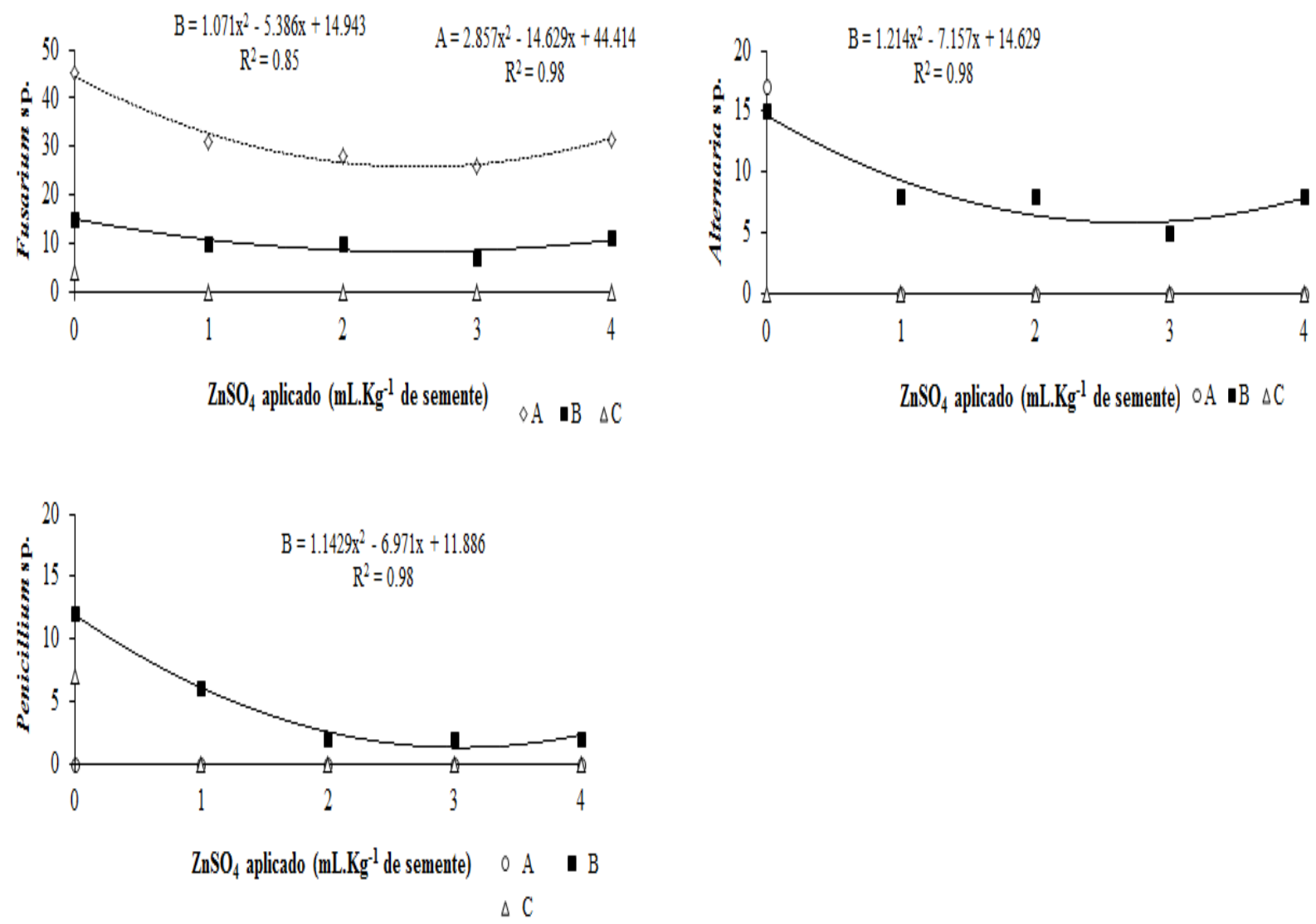

Figure 6. Sanitary test in wheat seeds, high and low quality lot, after coating with different doses of zinc. UFSM, Santa Maria, RS, Brazil. * A) initial data of germination; B) three months of storage; C) six months of storage.

At three months of storage, untreated seeds had a reduced incidence of Fusarium sp. 66.7\% and, had an incidence rate of $12 \%$ Penicillium sp. and $15 \%$ for Alternaria sp. However, Alternaria sp. it was maintained at all doses, but with reduced incidence of $46.5 \%$ at doses of 1,2 and $4 \mathrm{~mL}$ of $\mathrm{ZnSO}_{4}$ and $66.7 \%$ at a dose of $3 \mathrm{~mL}$ of $\mathrm{ZnSO}_{4}$. Within six months storage, no difference was detected between different doses of $\mathrm{ZnSO}_{4}$, both of field and storage fungi (Figure 6).

All treatments were effective in controlling Penicillium sp, Fusarium sp. and Alternaria sp., being possible elimination of these fungi in seeds at the end of storage, demonstrating the effectiveness of treatment with zinc + fungicide + polymer and water, besides confirming that seed coating did not affect the efficiency of fungicide treatment. Probably, the addition of polymer has promoted an antifungal effect, or forming a mechanical barrier, which may have hindered the development of fungi and facilitated direct contact of products (fungicide + zinc) with seeds. When testing the application of polymers in chemical treatment of soybean seeds by Reis et al., (2005) found that its addition allows a better distribution and adhesion of chemicals on seed, which made the treatment more efficient and allowed the reduction of pathogens from seeds. However, according to Henning et al., (2003), polymers should only be used in conjunction with fungicides, because they do not protect seeds on the soil, resulting in poor seedling emergence.

Fungi found in wheat seeds from low quality lot, for six months of storage, were Fusarium sp., Alternaria sp., Penicillium sp and Aspergillus sp. In initial evaluation of seeds from low quality lot (Figure 7), it is noteworthy that the number of seeds contaminated by Penicillium sp. $(29 \%)$ was higher than incidence fungi (Aspergillus sp. (18\%) and Fusarium sp. (12\%), which appears to have caused intense negative effect on seeds metabolism. Quite often, the incidence rates observed in this study, in wheat seed lot sold, at harvest with high humidity. It is 
noteworthy that increasing doses of $\mathrm{ZnSO}_{4}$ reduced the incidence of fungi mentioned above.
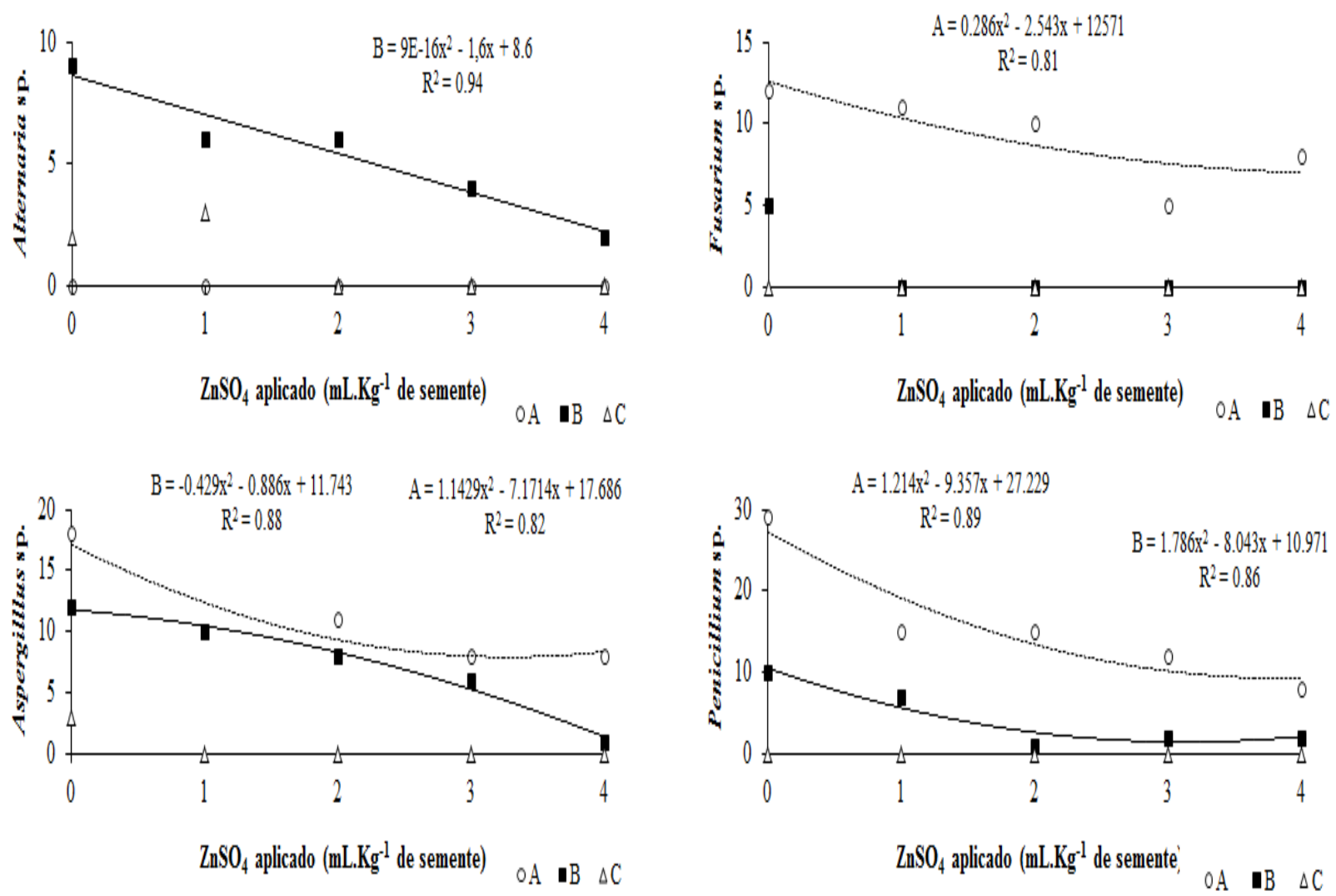

Figure 7. Sanitary test in wheat seeds, high and low quality lot after coating with different doses of zinc. UFSM, Santa Maria, RS, Brasil. * A) initial data of germination; B) three months of storage; C) six months of storage.

Within three months of storage, three fungi found in the initial analysis, remained in untreated seeds, but with lower incidence: Penicillium sp. (10\%) and Aspergillus sp. (12\%). This lot was also found within three months of storage, Alternaria sp., which had not been previously detected, with a $6 \%$ incidence in untreated seeds. Alternaria sp. has also been found with a $6 \%$ incidence at doses of 1 and 2 $\mathrm{mL}, 4 \%$ at a dose of $3 \mathrm{~mL}$ and $2 \%$ at a dose of 4 $\mathrm{mL}$. In the period of six months storage, no difference was found in the incidence of Fusarium sp, Alternaria sp., Penicillium sp. and Aspergillus sp. between different doses of $\mathrm{ZnSO}_{4}$ applied to wheat seed.

Mineral nutrition, as environmental factors, can be manipulated with relative ease to control diseases. However, you need a detailed knowledge of how mineral nutrients increase or decrease the resistance of plants (MARSCHNER, 1995). According to Ribeiro et al. (1994), increased expression of germination of wheat may be due to improvements in health, in response to seed treatment with zinc. However, Lima et al. (2010) observed no differences with addition of different doses of zinc to reduce pathogens in soybean.

Low levels of zinc in seed resulting in the inability of tissues grow normally, the leaves may become twisted and necrotic, flowering and grain filling can be greatly reduced. This deficiency can also be detected at cellular level, by malformation of organelles such as chloroplasts and mitochondria and cause further problems in cell division and twisted roots with tips expanded (MALAVOLTA, 2006) and thus become susceptible to pathogens.

The reduction of pathogens in seed due to zinc effect, the result is usually the influence of specific forms of the nutrient in different metabolic pathways, thus altering the constituents of the plant.

\section{CONCLUSIONS}

Wheat seed coating with zinc sulfate at doses 3-4 mL kg ${ }^{-1}$ seed, are effective in maximizing 
the physiological quality of seeds, up to six months of storage.
Zinc associated with fungicide and polymer results in lower incidence of fungi on seeds during storage.

RESUMO: O objetivo do presente trabalho foi avaliar o efeito do recobrimento de sementes de trigo com zinco, por meio de atributos fisiológicos e sanitários durante o armazenamento. Foram utilizados dois lotes de sementes e para tratamento, utilizou-se produto comercial com fonte de zinco na forma de $\mathrm{ZnSO}_{4}$, fungicida e polímero. Foram testados níveis de $0 ; 1 ; 2 ; 3$ e $4 \mathrm{~mL}$ de $\mathrm{ZnSO}_{4} \cdot \mathrm{kg}^{-1}$ de semente. A avaliação da qualidade fisiológica, durante o período de armazenamento foi realizada por: teor de água, peso hectolítrico, germinação, emergência de plântulas, índice de velocidade de emergência e teste de tetrazólio e o teste de sanidade. Concluiu-se que o recobrimento de sementes de trigo com sulfato de zinco nas doses de 3 a $4 \mathrm{~mL} . \mathrm{kg}^{-1}$ de semente, são eficientes na maximização da qualidade físiológica das sementes, até seis meses de armazenamento. Este recobrimento promove menor redução na viabilidade das sementes, além disso, resulta em menor incidência de fungos nas sementes durante o armazenamento. Também auxiliam na maximização da expressão da qualidade fisiológica das sementes de maior e menor qualidade, respectivamente. O micronutriente zinco associado com fungicida e polímero apresentaram menor incidência de fungos ao longo do período de armazenamento.

PALAVRAS-CHAVE: Triticum aestivum L. Qualidade fisiológica. Tratamento de sementes. Sanidade.

\section{REFERENCES}

ALBUQUERQUE, K.A.D.; OLIVEIRA, J.A.; VEIGA, A.D.; CARVALHO, B.O.; ALVIM, P.O. Armazenamento e qualidade de sementes de tomate enriquecidas com micronutrientes e reguladores de crescimento. Ciência e agrotecnologia, Lavras, v.34, n.1, p.20-28, 2010. http://www.scielo.br/scielo.php?script=sci_arttext\&pid=S1413-70542010000100002\&lng=en\&nrm=iso

AOSA. Association of Official Seed Analysts. Seed Vigour Testing Handbook. Ithaca, NY, USA. 2012. 93p.

BARNETT, H. L.; HUNTER, B. B. Illustrated genera of imperfect fungi. St Paul, Minnesota: APS Press, 1998. 218p.

BRASIL. Ministério da Agricultura, Pecuária e Abastecimento. Regras para Análise de Sementes/Ministério da Agricultura, Pecuária e Abastecimento. Secretaria de Defesa Agropecuária. - Brasília, DF: MAPA/ACS, 2009. 399p.

FERREIRA, D. F. Análises estatísticas por meio do SISVAR para Windows versão 4.0. In: REUNIÃO ANUAL DA REGIÃO BRASILEIRA DA SOCIEDADE INTERNACIONAL DE BIOMETRIA (RBRAS), 45., 2000, São Carlos, SP. Anais... São Carlos: UFSCar, 2000. p. 255-258.

FUNGUETTO, C. I.; PINTO, J. F; BAUDET, L.; PESKE, S. T. Desempenho de sementes de arroz irrigado recobertas com zinco. Revista brasileira de sementes, Londrina, vol. 32, n.2, pp. 117-123, 2010.http://www.scielo.br/scielo.php?script=sci_arttext\&pid=S0101-31222010000200014\&lng=en\&nrm=iso. GUARIENTI, E. Qualidade industrial de trigo. 2.ed. Passo Fundo: Embrapa-CNPT, 1996. 36p.

HENNING, A. A.; FRANÇA NETO, J. B.; KRZYZANOWSKY, F. C.; COSTA, N. P. Avaliação de corantes, polímeros, pigmentos e fungicidas para o tratamento de sementes de soja. In: CONGRESSO BRASILEIRO DE SEMENTES, 13., 2003, Londrina. Informativo ABRATES, Londrina, v. 13, n. 3, 2003.

ISTA - International seed testing association. Biochemical test for viability: the topographical tetrazolium test. (ed.) International rules for seed testing. ed. 2008. Bassersdorf, 2008. cap.6, p.6.1-6.30.

LIMA, L. B.; SILVA, P. A.; GUIMARAES, R. M.; OLIVEIRA, J. A. Peliculização e tratamento químico de sementes de algodoeiro (Gossypium hirsutum L.). Ciência e agrotecnologia, Lavras, vol.30, n.6, pp. 10911098, 2006. http://www.scielo.br/scielo.php?script=sci_arttext\&pid=S1413-

$70542006000600007 \& \operatorname{lng}=$ en\&nrm=iso 
LIMA, L.M.; POZZA, E.A.; POZZA, A.A.A.; FONSECA, T. A.P.S.; CARVALHO, J.G. Quantificação da ferrugem asiática e aspectos nutricionais de soja suprida com silício em solução nutritiva. Summa phytopatholica, Botucatu, vol.36, n.1, pp. 51-56, 2010.

http://www.scielo.br/scielo.php?script=sci_arttext\&pid=S0100-54052010000100009\&lng=en\&nrm=iso

MAGUIRE, J. D. Speed of germination-aid in selection and evaluation for seedling emergence and vigour. Crop Science, Madison, v.2, n.1, p.176-177, 1962.

http://dx.doi.org/10.2135/cropsci1962.0011183X000200020033x

MALAVOLTA, E. Manual de nutrição mineral de plantas. Viçosa: UFV, 2006. 631 p.

MARSCHNER, H. Mineral nutrition of higher plants. 2. ed. New York: Academy Press, 1995. 887 p.

MELLO PRADO, R.; COSTA, R. S. S.; FRADE Jr., E. F.; MOUTA, E. R.; SÃO JOÃO, A. C. G. Crescimento inicial e estado nutricional do trigo submetido à aplicação de zinco via semente. Revista de la ciencia del suelo y nutrición vegetal, Temuco, vol.7, n.2, pp. 22-31, 2007.

http://www.scielo.cl/scielo.php?script=sci_arttext\&pid=S0718-27912007000200003\&lng=pt\&nrm=iso

NAKAGAWA, J. Testes de vigor baseado do desempenho das plântulas. In: KRZYZANOWSKI, F. C; VIEIRA, R. D; FRANÇA NETO, J. B. Vigor de sementes. Conceitos e Teses. Londrina, 1999. p. 2-1/2-24.

OHSE, S.; MARODIM, V.; SANTOS, O. S.; LOPES, S. J.; MANFRON, P. A. Germinação e vigor de sementes de arroz irrigado tratadas com zinco, boro e cobre. Revista Faculdade Zootecnia, Veterinária e Agronomia, Uruguaiana, v. 7, n. 1, p.73-79. 2000.

PEREIRA, C. P.; OLIVEIRA, J. A.; EVANGELISTA, J. R. E. Qualidade fisiológica de sementes de milho tratadas associadas a polímeros durante o armazenamento. Ciência e Agrotecnologia, Lavras, v. 29, n. 6, p.1201-1208, 2005. http://www.scielo.br/scielo.php?script=sci_arttext\&pid=S1413$70542005000600014 \& \operatorname{lng}=$ en\&nrm=iso

REIS, E. M.; BENIN, F. J.; MEGGIOLARO, E.; FANTINI, S. Uso de polímeros no tratamento de sementes. In: Anuário ABRASEM 2005. Associação Brasileira de Sementes e Mudas, Pelotas, 2005, p.38-39.

RIBEIRO, N. D.; SANTOS, O. S. Aproveitamento do zinco aplicado na semente na nutrição da planta. Ciência Rural, Santa Maria, v. 26, n. 1, p. 159-165, 1996.

http://www.scielo.br/scielo.php?script=sci_arttext\&pid=S0103-84781996000100030\&lng=en\&nrm=iso

RIBEIRO, N. D.; SANTOS, O. S. dos; MENEZES, N. L. Efeito do tratamento com fontes de zinco e boro na germinação e vigor de sementes de milho. Scientia Agricola, Piracicaba v. 51, p. 481-485, 1994. http://dx.doi.org/10.1590/S0103-90161994000300017

TRENTINI, P.; VIEIRA, M. G. G. C.; CARVALHO, M. L. M.; OLIVEIRA, J. A. O.; MACHADO, J. C. Peliculização: desempenho de sementes de soja no estabelecimento da cultura em campo na região de Alto Garças, MT. Ciência e Agrotecnologia, Lavras v. 29, n. 1, p. 84-92, 2005.

http://www.scielo.br/scielo.php?script=sci_arttext\&pid=S1413-70542005000100010\&lng=en\&nrm=iso

VIEIRA, E. H. N.; MOREIRA, G. A. Peletização de sementes de arroz. Santo Antônio de Goiás: Embrapa Arroz e Feijão, 2005, 2p. (Embrapa Arroz e Feijão. Comunicado Técnico, 111).

YAGI, R.; SIMILI, F. F.; ARAUJO, J. C.; MELLO PRADO, R.; SANCHEZ, S. V.; RIBEIRO, C. E. R. R; BARRETO, V. C. M. Aplicação de zinco via sementes e seu efeito na germinação, nutrição e desenvolvimento inicial do sorgo. Pesquisa Agropecuária Brasileira, Brasília v.41, n.4, p.655-660, 2006.

http://www.scielo.br/scielo.php?script=sci_arttext\&pid=S0100-204X2006000400016\&lng=en\&nrm=is 